\title{
Forests, food, and fuel in the tropics: the uneven social and ecological consequences of the emerging political economy of biofuels
}

\author{
Peter Dauvergne and Kate J. Neville
}

Version Post-Print/Accepted Manuscript

Citation Dauvergne, P., \& Neville, K.J. 2010. Forests, food, and fuel in the (published version) tropics: the uneven social and ecological consequences of the emerging political economy of biofuels. Journal of Peasant Studies, 37(4): 631-660

Publisher's Statement This is an Accepted Manuscript of an article published by Taylor \& Francis in Journal of Peasant Studies on September 23, 2010, available online: http://www.tandfonline.com/ 10.1080/03066150.2010.512451.

\section{How to cite TSpace items}

Always cite the published version, so the author(s) will receive recognition through services that track citation counts, e.g. Scopus. If you need to cite the page number of the TSpace version (original manuscript or accepted manuscript) because you cannot access the published version, then cite the TSpace version in addition to the published version using the permanent URI (handle) found on the record page. 


\title{
Forests, food, and fuel in the tropics: the uneven social and ecological consequences of the emerging political economy of biofuels
}

\author{
Peter Dauvergne and Kate J. Neville
}

\begin{abstract}
The global political economy of biofuels emerging since 2007 appears set to intensify inequalities among the countries and rural peoples of the global South. Looking through a global political economy lens, this article analyses the consequences of proliferating biofuel alliances among multinational corporations, governments, and domestic producers. Since many major biofuel feedstocks - such as sugar, oil palm, and soy - are already entrenched in industrial agricultural and forestry production systems, the authors extrapolate from patterns of production for these crops to bolster their argument that state capacities, the timing of market entry, existing institutions, and historical state-society land tenure relations will particularly affect the potential consequences of further biofuel development. Although the impacts of biofuels vary by region and feedstock, and although some agrarian communities in some countries of the global South are poised to benefit, the analysis suggests that already-vulnerable people and communities will bear a disproportionate share of the costs of biofuel development, particularly for biofuels from crops already embedded in industrial production systems. A core reason, this article argues, is that the emerging biofuel alliances are reinforcing processes and structures that increase pressures on the ecological integrity of tropical forests and further wrest control of resources from subsistence farmers, indigenous peoples, and people with insecure land rights. Even the development of so-called 'sustainable' biofuels looks set to displace livelihoods and reinforce and extend previous waves of hardship for such marginalised peoples.
\end{abstract}

Keywords: biofuel alliances, global political economy, institutions, state-society relations, sustainability

The global political economy of biofuels has been shifting direction since 2007 , as investments in alternative energy continue to grow, as chains of production and consumption crisscross and deepen in new regions, and as governments and corporations reassess economic prospects and political obstacles. Preceding the 2007 food crisis, many analysts saw biofuels as a pathway toward more sustainable development, with the potential to support small-scale farmers, develop rural economies, and reduce greenhouse gases. This cautious optimism dampened after biofuels were linked to higher food prices and deforestation, and as scientific studies put into doubt their carbon neutral status, especially those derived from food crops. In response,

We extend thanks to three anonymous reviewers for their extensive and insightful comments, as well as to Jun Borras, lan Scoones, Phil McMichael, John McCarthy, and the participants of the JPS workshop on 'Biofuels, Land and Agrarian Change' (hosted by the International Development Studies Program at Saint Mary's University, 16-17 October 2009) for comments on an earlier draft. We are grateful for funding support from the Social Sciences and Humanities Research Council of Canada. 
biofuel investors and producers launched new alliances to advance the industry. The effects of these new partnerships and interests extend beyond their impacts on food prices and security. Internationally, the emerging economics of the biofuel industry are altering relations among states and between states and industry, especially with multinational corporations (MNCs). ${ }^{1}$ Domestically, these alliances are affecting land tenure and livelihoods of diverse rural groups in ways that mimic destructive patterns already common in industrial forestry and agriculture. ${ }^{2}$

This paper explores how this emerging political economy of biofuels is shaping ecological change in rural communities in tropical forest regions, through an analysis of economic and political alliances at the international and domestic levels. We argue that the consequences of emerging alliances among MNCs, governments, and domestic corporations depend in large part on the institutional structures of the state, the timing of entry into the biofuel market, and on historical state-society relations. In many cases, biofuel development looks set to further wrest control of the land - and products of the land - from subsistence farmers, indigenous peoples, forest-dependent communities, ${ }^{3}$ and people with insecure land rights. ${ }^{4}$ In light of past experiences when introducing new technologies and commercialising agriculture and forestry, we anticipate that even the promotion of so-called 'sustainable' biofuels by emerging economies of the South (primarily large-scale and corporate-influenced biofuel development) will reinforce and extend previous waves of livelihood displacement. In particular, we draw on evidence of the effects on agrarian communities of the production of crops like soy, sugarcane, and oil palm (major food crops as well as biofuel feedstocks), from

\footnotetext{
${ }^{1}$ For a more detailed analysis of these changes, see Dauvergne and Neville (2009).

${ }^{2}$ We use the term 'livelihoods' to refer to the activities of subsistence and income generation for individuals and households. See Scoones (2009) for a full discussion of the meaning and implications of livelihood perspectives in the development literature.

${ }^{3} \mathrm{We}$ use the term 'forest-dependent' to indicate communities that rely on forest products and livelihood activities, such as non-timber forest products (NTFPs) including cultivated and gathered seasonal foods and medicines. These communities may be agrarian, but rely to some extent on the forests to complement and buffer against fluctuations in other income-producing and subsistence activities (see Belcher and Schreckenberg 2007 on the effects of commercialisation of NTFPs on communities and especially poor households). In agrarian communities, landless families may have the highest dependence on forests. Santra et al. (2008) document the forest-dependence of farmers in south-west Bengal, noting that, on average, landless families visit the forest 6 days a week, while landowning families' visits are closer to 4 days a week; Vedeld et al. (2007) document the equalizing effects on local income distribution of 'environmental incomes' from forest products like fuelwood and fodder.

${ }^{4}$ Insecure land tenure might be the result of a lack of formal title, but might also be the product of a government's disregard for formal land rights (see, for example, Broegaard 2005 on perceived insecurity despite formal land tenure in Nicaragua).
} 
which we extrapolate to reflect on what we see as the likely uneven social and ecological trajectories of further biofuel development.

To guide our analysis, we track four related questions. First, what are the implications of emerging biofuel alliances for state control over, and benefits from, industrial development? Second, in cases where states have relatively little influence within these alliances, to what extent can voluntary corporate policies to promote social and environmental responsibility offset the lack of regulatory oversight? Third, which rural groups seem most likely to benefit or lose out from resulting economic opportunities and outcomes? And fourth, what are the direct and indirect consequences for forests (and nearby ecosystems and land) of an emerging political economy of higher biofuel production?

Our analysis proceeds in three parts. First, we review the changing global architecture of the biofuel sector. We outline the increase in South-South trade and investment, the emergence of powerful states in the global South, and the surge in - and backlash against biofuel development over the last decade. We also present additional illustrative evidence of links between MNCs and developing countries to reinforce our claims that emerging Southern states are acting in ways that echo the patterns of resource exploitation by Northern ones.

Second, we consider what the emerging biofuel industry implies for states, particularly their capacity to derive national economic benefits. Examining the recent surge in partnerships linking MNCs with local firms and governments, we draw on theoretical work on state strength (Migdal 1988, Dauvergne 1998a), state size and development levels (Krasner 1976), timing of industrial development (Evans 1995), and the institutional basis for technology uptake and benefits (Peluso and Vandergeest 2001, Acemoglu and Robinson 2009), to suggest likely trajectories of these biofuel alliances across countries. Based on past patterns of development and multinational investment in agriculture and forestry, we argue that, as the biofuel sector grows, it will become more difficult for states and local communities to derive diffuse public (instead of concentrated private) benefits from production. Previous analyses suggest that this challenge will be most pronounced for states with incentives to act predatory, rather than developmental (Migdal 1988, Evans 1995, Bates 2008, Petras and Veltmeyer 2007). Further, in the absence of state regulatory oversight and control, voluntary corporate initiatives seem 
unlikely to provide substantial environmental and social protection, given the limited success to date of corporate social responsibility (CSR) initiatives in related sectors such as agrifoods (as documented by Utting and Clapp 2008, Clapp and Fuchs 2009).

Third, we evaluate the subnational distributional consequences of biofuel development. Groups within a state, we find, may still take on a significant burden even in states that benefit in terms of standard national economic indicators. We consider the human and ecological costs of biofuels through a lens that combines Taylor and Garcia-Barrios' (1995) framework for a social analysis of ecological change - modeled after Parayil and Tong's (1998) application of this framework - with an analysis of historical and continued exclusion by states of marginal rural groups. We bring with work on peasant differentiation (e.g., Byres 2009) to understand the material and social factors that allow some groups, but not others, to take advantage of the opportunities from emerging biofuel markets. As with states' differential abilities to capitalise on biofuels based on their existing institutions, the already-established political and economic resources of groups within the state provide unequal opportunities for groups to benefit from these new commodity markets.

We focus in particular on the framing of the debate over sustainable biofuels, arguing that it is both powerful and misleading. The rhetoric of sustainability creates a discourse that is difficult for critics of biofuels to challenge, as it appeals to widely-accepted norms and goals of the international community. However, the ways in which production is taken up tends to exclude the perspectives, interests, and livelihoods of marginalised communities, especially those with insecure land tenure. Although they can be produced at a small, local scale, crops such as sugar, oil palm, and soy lend themselves readily to large-scale plantations and exportoriented production. Since these biofuel feedstocks have already been developed in this way in the agricultural sector, with substantial MNC control, the diversion of crops from food to fuel production has little chance of changing these industrial-scale systems (and the evidence to date indicates that the added incentives for production are only intensifying these trends).

Although biofuels differ in their ecology, production demands, and market opportunities, we nonetheless see parallel processes of encroachment of agricultural lands and plantations into natural forests by producers of multiple feedstocks, including sugarcane, oil 
palm, soy, and Jatropha curcas. ${ }^{5}$ Consequently, we extend the general biofuel 'trilemma' of food security, energy, and biodiversity (as termed by Tilman et al. 2009) to include concerns about forest-dependent communities; we also contest some recent literature that is encouraging more open trade as a strategy to enhance the potential for biofuels to bring equitable development to poor regions.

In our conclusions, we reflect on the potential of biofuels as a pathway to more ecologically and socially sustainable development. Investment in biofuels is certainly providing some economic opportunities in some developing countries with the potential to catalyse further development in some rural areas. Globally, biofuels also have the potential to help in the search for solutions to climate change and energy security. ${ }^{6}$ We caution, however, that the opportunities are uneven, with some states able to benefit far more than others. Moreover, in countries that can capitalise on biofuels, even small-scale production needs to consider very carefully the effects on vulnerable forest communities and people with insecure land rights, and the consequent displacement of livelihood and subsistence pressures onto surrounding natural forests.

\section{The emerging South-South political economy of biofuels}

Our previous research (Dauvergne and Neville 2009) found that biofuel investment and trade among developing countries is repeating earlier biofuel relations between Northern and Southern countries. Increasingly powerful Southern countries are providing incentives to their less developed counterparts to produce biofuels, with varying environmental and economic repercussions. This South-South political economy of biofuels is part of a larger political

\footnotetext{
${ }^{5}$ There are significant differences in what McCarthy $(2009,19)$ terms 'commodity-specific factors' of different biofuel feedstocks, where ecological characteristics vary by crop type and have implications for the ways in, and scale at which, they are grown, harvested, and processed. Moreover, regional and local differences exist in the environmental and social conditions in which these feedstocks are produced. Nevertheless, a growing number of studies indicate that in spite of these differences - across biofuel types and production locations - there are similar and considerable environmental and human costs, as well as opportunities, from biofuel development (see, for example, Hunsberger in this volume, for Jatropha in Kenya; Vel in this volume, for Jatropha in Indonesia; Wilkinson and Herrera in this volume, for sugarcane and soy in Brazil; Pye in this volume, for oil palm in Indonesia; and Franco et al. in this volume, for sugarcane and Jatropha in Mozambique).

${ }^{6}$ Note, however, that there is some doubt that biofuels can achieve greenhouse gas emission reductions (see, for instance, Righelato and Spracklen (2007), and Pimentel and Patzek (2005) for discussions of various feedstocks) and that biofuels are replacing, rather than supplementing, fossil fuels.
} 
economy of the environment, in which more powerful economies are deepening relationships with MNCs. This changing global economic architecture, we found, is adding to already unsustainable resource exploitation and environmental degradation in many developing countries.

In this section, we briefly summarise these earlier findings, explaining the biofuel industry, describing the surge of interest in and recent backlash against biofuels, and outlining the economic and political indicators of changing South-South biofuel relations. The trends in biofuels are new, and thus to some extent still uncertain. We can draw, however, on welldocumented patterns of exploitation in related industries, such as soy in Latin America and oil palm in Southeast Asia, to reflect on what outcomes we might expect from further development of biofuels. Our argument rests in part on the proliferation of partnerships among developing country investors, developing country biofuel producers, MNCs from the North and South, and domestic firms in these developing countries, and so we present additional evidence of a growing number of these transnational partnerships. Many of these alliances are in early stages, and so it remains to be seen if there will be follow through, but the initial commitments suggest new sets of investment partners within the global financial system.

\section{a. The biofuel context}

Bioethanol and biodiesel are non-petroleum based liquid fuels, derived largely from plants and plant oils. Divided into categories based on the sources, or 'feedstocks', from which they derive, biofuels have differing impacts on carbon emissions, food crops, and the environment. 'Firstgeneration' fuels are produced from food crops, including palm oil, rapeseed, sugarcane, and corn. In contrast, the sources of 'second-generation' fuels are non-food crops, like switchgrass and Jatropha curcas, or the residual inedible parts of food crops, such as the husks and stems of corn. 'Third-generation' biofuels are derived from algae. While first-generation biofuels are in full-scale production, second- and third-generation ones are not yet commercially viable at a global scale, although research and development are progressing.

Sources used for biofuels vary by geographic location, and largely map on to pre-existing agricultural production in those regions: corn-based biofuels are dominant in the United States 
(US), sugarcane in Brazil, rapeseed in the European Union (EU), and oil palm in Indonesia and Malaysia. Biofuels differ in the inputs needed for production, and, consequently, their total net energy and carbon balances. These values depend on geographic factors, agricultural methods, the extent and type of land use conversion undertaken, along with the pesticides, fertilisers, and technology involved in their production (McCarthy 2009). The potential of biofuels to mitigate climate change, and contribute to positive overall change depend on these factors, as well as on the policies in place to develop them.

\section{b. Biofuel promotion: the surge and backlash}

Interest in biofuels as an alternative energy source surged in the late 1990s, especially in the US and EU. Although biofuel research and development had been underway throughout the twentieth century, particularly in Brazil, a confluence of concerns in the 1990s over climate change, energy security, and declining oil reserves sparked greater interest in the potential for biofuels to contribute to clean development. Brazil quickly emerged as a global leader in the sector, as it had already invested considerably in biofuels, particularly through the Brazilian Alcohol Program (Proalcool) in the 1970s. ${ }^{7}$

Support for biofuels ranged across industrial and environmental groups, with agricultural interests and many climate change activists expressing support. In the United Kingdom, for example, among those sharing enthusiasm for biofuels in the early 2000s were farmers, EU officials, national and municipal government representatives, the Royal Society for the Protection of Birds, Friends of the Earth, and Greenpeace. Agricultural, oil, and automotive lobbies and corporations, including corn producers in the US, rapeseed producers in Germany, and MNCs like Archer Daniels Midland (ADM) were intrigued by the possibility of new and vast markets (Accenture 2007, Kurdusiewicz and Wandesforde-Smith 2008). Many governments were keen on the potential of biofuels to meet climate change commitments and reduce dependence on foreign oil. And numerous environmental activists supported the idea of developing biofuels as an alternative energy source.

\footnotetext{
${ }^{7}$ See Moreira et al. $(2005,28-30)$ for a history of Brazil's early investment in biofuels, including the quadrupling of sugar production from 1975 to 1986. Low oil prices in the late 1980s and early 1990s combined with the removal of government subsidies slowed the biofuel sector, but it was able to capitalise on its early progress when global interest surged.
} 
Cautionary voices were heard at the time, with groups including the WWF and Birdlife International raising concerns that developing biofuels would threaten biodiversity by stimulating land use conversion; some called for lifecycle analyses to assess the trade-offs of water, soil, and energy use (e.g., Pimentel 2003, Punter et al. 2004). While support was by no means universal or unqualified, there was nonetheless considerable optimism that biofuels could simultaneously promote ecological, economic, and social goals. Even those with reservations about the unintended effects of production - such as the re-direction of food crops to fuel, or the use of genetically modified crops to increase yields - were reluctant to coordinate resistance against efforts to promote alternative energy, particularly since the promise of later-generation biofuels, with seemingly fewer negative side effects, could not be realised without support for the sector in its early stages.

This optimism and forward momentum continued through 2006. The EU and the US enacted policies to develop biofuels, such as the 2003 Biofuel Directive in the EU. By then analysts were anticipating that biofuel imports into the EU would grow as European countries strove to meet their new commitments, since the availability of land limited the projected ability of many member states to be self-sufficient in biofuel supply (Ringwald 2006, 5-6).

These dynamics changed suddenly in 2007 , as spikes in food prices led to a global crisis. Biofuels garnered intense media coverage as the food crisis sparked riots in Haiti, Yemen, Zimbabwe, and other countries. These demonstrations, called 'food riots' by some and 'fuel riots' by others, put a spotlight on the convergence of multiple pressures on agricultural and financial systems, with purchasing power and food availability affected by factors, including: the rising prices of staple crops, such as rice, wheat, and corn; growing populations and increased incomes in emerging economies, such as China and India; and market speculation in food commodities following the collapse of housing markets.

During this time uncertainty also began to increase around the environmental benefits of biofuels as more scientists raised doubts about the net carbon footprint of many biofuels. The journal Science, for example, published two influential articles in 2008 indicating that several biofuels - particularly those derived from food crops in the US, Brazil, and Southeast 
Asia - incurred even higher environmental costs than traditional fossil fuels, creating a carbon debt rather than a carbon saving (Scharlemann and Laurance 2008, Fargione et al. 2008).

International organisations and governments responded to the critiques in various ways, with some undertaking their own analyses of the impact of biofuels on food prices. These yielded widely divergent findings. Estimates of the influence of biofuels on food prices ranged, for example, from a low of 2-3 percent by the US administration (AP 2008) to a high of 75 percent in an internal World Bank draft report leaked to the Guardian newspaper (Chakrabortty 2008). In response to these converging doubts about biofuels, the EU moderated its early enthusiasm for biofuels by postponing deadlines for decisions on renewable energy guidelines. Eventual legislation, adopted in April 2009, required that emissions savings and sustainability criteria must be met before biofuels could be counted toward renewable energy targets.

While more cautious interest in biofuels within Europe lowered market growth projections, it did not stifle all growth in the sector. New partnerships formed to support the industry, with many seeing a growing consumer base for energy in the emerging economies of the South as a critical source of demand.

\section{c. Growing South-South investments}

Evidence of changing relationships in the world economy comes in several forms. First, we can identify macro-scale patterns of economic growth in a subset of developing countries, revealing a divergence among countries in the global South and a convergence between some of these developing countries and those of the North. Second, we can track aggregated patterns of investment within developing countries, showing that the sources of foreign direct investment (FDI) now include more developing countries. Third, we can examine particular investments to chart which companies and countries are involved in resource development and partnerships. Consequently, in our previous study (Dauvergne and Neville 2009), we linked the growing economic power of countries like Brazil and India with data on the increase in South-South trade, noting that for biofuels these emerging economies were joining developed countries as core investors in the global South. In conjunction with reports of new business ventures for biofuels involving some of these developing country leaders, MNCs, and the governments and 
local firms of other developing countries, we inferred that some Southern countries are taking on roles in industrial biofuel development that have been traditionally held by Northern countries.

Drawing on phrases like 'South-South cooperation' and 'sustainable development', developing country leaders have carved out a niche and attempted to build a comparative advantage in the sector, particularly in terms of promoting investment in, and resource extraction from, other developing countries. However, as we looked into the biofuel alliances, it became clear that these leaders have not supplanted developed country investors through this framing, but rather have joined and partnered with them, with demand from developing country consumers supplementing demand from the North.

To capture more general, large-scale patterns of economic growth, analysts have highlighted a number of emerging economies. Known in various groupings as BRIC and BRICSAM, among other acronyms, these include Brazil, Russia, India, China, South Africa, the ASEAN (Association of Southeast Asian Nations) states, and Mexico; other core countries in international and regional contexts include Turkey, Egypt, Iran, and Nigeria (Cooper et al. 2007). South-South FDI and trade among developing countries have surged dramatically, with trade increasing from US\$577 billion in 1995 to over US\$2 trillion in 2006, with trade among Southern countries outpacing trade between developing and developed countries (Sumner 2008, Supachai 2008). Trade agreements among developing countries have also proliferated; Brazil, for example, has established nine separate regional trade agreements within Mercosur (Antkiewicz and Whalley 2006). ${ }^{8}$ Brazil, taking an active role in furthering these relationships, is engaging in cooperative initiatives with other developing countries (such as India and South Africa) to, in its president's words, 'enhance political dialogue and economic links with the Arab World, Africa, and Asia' (Lula da Silva 2007).

While South-South trade has substantially increased, the new trade and investment relationships are not limited to ties within the global South. Emerging economies have taken strategic action to improve their political and economic positions in the international arena. MNCs have also established headquarters in the BRICSAM countries (Cooper et al. 2007, 681),

\footnotetext{
${ }^{8}$ Martin (2008) and Campbell (2008), for example, examine South-South linkages, particularly between Asian and African countries.
} 
and, in the biofuel sector, developed and developing countries have formed political alliances. Despite early jockeying for dominance over biofuel markets between Brazil and the US - the primary producers of bioethanol - and despite continuing competition, at least for now the two countries seem to have put aside their differences to promote biofuels.

Initially, Brazil did claim that its sugarcane-based biofuels were economically and ecologically superior to American maize-based fuels. The absence of government subsidies for bioethanol production contributed to the claimed superiority of Brazilian biofuels, as, without US import taxes, in 2006 US bioethanol cost \$1.03/gallon while Brazilian bioethanol cost \$0.81/gallon (Moreira et al. 2005, 29, Goldemberg 2007). Brazilian President Lula da Silva's statement at a June 2008 meeting at the Food and Agriculture Organization is typical of the rhetoric at that time: 'corn ethanol can obviously only compete with sugarcane ethanol when it is shot up with subsidies and shielded behind tariff barriers' and further that 'some people compare ethanol to cholesterol... there is good ethanol and bad ethanol' (Lula da Silva 2008).

Since then, however, the discourse has shifted. A collaborative initiative between the two countries was announced in late 2008, with the US Department of State reporting that 'nine partner nations [are] to benefit from US-Brazil biofuels collaboration' (USDS 2008). SouthSouth relationships have not replaced North-South ones, but instead have led to an increasing number of 'North-South-South' linkages, in 'triangular' projects. These linkages have tangled governments of the North and South with the private sector, in partnerships that span the globe. Growing evidence suggests that biofuels are following the same trajectory as other, related, agricultural and forestry industries.

Evidence of new South-South dynamics is found in the increasing number of partnerships and investments that involve developing country governments and corporations across multiple countries. Mauritian companies have funded biofuel initiatives in Mozambique and a bioethanol project in the Philippines has involved an Indian engineering company. Biofuel development in Asia and Africa follows similar international paths, with the India State Trading Corporation considering land purchases in Indonesia and Suriname; South Korean and Singaporean companies expressing interest in other Asian countries' feedstock production; a Nigerian biofuel refinery developed by a consortium comprising the African Development Bank, 
a state university of the Philippines, and several Nigerian banks; and participants in Mozambique's biofuel development including Petrobras (Brazil), ENI (Italy), Energem Resources (Canada), and the Central African Mining and Exploration Company. More recently, and along similar lines, the Malaysian company Sime Darby plans to invest in oil palm and rubber plantations in Liberia, and Chinese firms are investing in oil palm plantations in the Democratic Republic of the Congo.

\section{d. The ecological implications of the South-South political economy of biofuels}

Many of the new alliances reveal the growing economic and political strength of some developing countries - such as Brazil and Indonesia - as corporations and governments from these places extend trade and financial relations in both the North and South. However, despite the emergence of new powerful players, the patterns of environmental degradation and social dislocation associated with industrial resource production and extraction do not appear to have changed, nor does the influence of MNCs in these activities appear to be diminishing. Beyond the South-South investments and trade in biofuels, MNCs are active in both financing and advocating for the industry. Notably, agricultural and chemical companies joined forces to promote biofuels in the US, with Archer Daniels Midland, DuPont, Deere \& Co., and Monsanto establishing the Alliance for Abundant Food and Energy in 2008.

The environmental impacts of the oil palm industry offer some indication of the potential harm biofuel production could cause. In part, this reflects more general trends in industrial production of agricultural and forestry crops; moreover, oil palm is currently only a minor source of biofuel feedstock, but is poised to become a major source in the near future. Although currently the US and Brazil produce over 70 percent of the world's bioethanol, and the EU over 60 percent of biodiesel (Forge 2007, 2, Davis 2007), for biodiesel this appears set to change as Indonesia and Malaysia, among other countries, increase oil palm-based production of fuel.

Palm oil is used extensively in the food sector, for everything from deep-frying to margarine to processed cereals. Pesticides and fertilisers used in oil palm plantations can damage the environment, but the ecological impact of displacing agricultural activities and 
standing forests often overshadows this (Donald 2004). In places like the outer islands of Indonesia, which has a history of weak regulation of the forest industry (Dauvergne 1997, 2001, Smith et al. 2003, Pin Koh and Wilcove 2007), plantation crops, like oil palm and rubber, are typically planted on land that companies first cleared by burning down a 'degraded' forest. Often, this is an old-growth forest that loggers have combed over several times to truck out the most valuable timber. Burning is a cheap clearing method and adds valuable nutrients to the soil. But it also releases significant greenhouse gases, especially as fires commonly rage out-ofcontrol and engulf vast areas, including setting on fire underground peat moss. Over the last few decades, forest fires in Indonesia have frequently spread a smothering haze over Malaysia and Singapore, contributing not only to severe health problems for locals, but also releasing millions of tonnes of carbon into the atmosphere (see, for instance, Dauvergne's 1998b analysis of fires that swept across the country, destroying hundreds of thousands of hectares of forest). Whether oil palm is planted directly on newly cleared land or supplants rubber production that first replaced the forests, it contributes to, or at least fails to mediate, the environmental damage caused by such deforestation.

Economic growth and new channels to participate in the global economy do provide some benefits for poor people. Investments from more powerful developing countries into lesspowerful ones may also re-shape the dynamics of global economic and political power in ways that promote greater equity. Nevertheless, new technologies and industries run the risk of encouraging producers and elites to seize short-term profits over long-term investments in environmentally and socially-sustainable practices. Biofuel production in particular seems prone to driving up land and food prices, while creating incentives for increased land use conversion and deforestation. Such changes seem to affect poorer countries disproportionately, shifting the costs of resource-based industries onto the most vulnerable countries and communities. Adding to already-existing pressures on threatened ecosystems, this undermines the potential of biofuels to support both economic and environmental wellbeing.

At the macro-level, biofuel development depends on the dynamics of the global political economy. Investments, market speculation, and consumer demand have driven the changes in 
conventional energy and in biofuel prices, and the patterns of political and corporate interactions are influencing the further expansion of the sector. With already-high levels of MNC involvement in production of crops like soybeans and plantations like oil palm - and with soy and oil palm representing two growing sources of biofuel feedstocks - we anticipate similar future patterns in biofuels as for soybeans and oil palm in the past. In the next section, we examine the relationships among states and corporate actors, to assess which states are likely to benefit from the continued industrialisation of biofuel production.

\section{Emerging alliances of forests, food, and fuel}

The dynamics and impacts of the global biofuel industry are still emerging. Early patterns nonetheless provide us with evidence of the direction in which it is currently moving. The political economy literature on the patterns of international trade relationships for the development of new technology, particularly in the construction of comparative advantages in production, also provides some indication of the trajectory of the biofuel sector at the state level. Moreover, although biofuels are a relatively new technology on the international stage, the primary and emerging large-scale feedstocks - notably rapeseed, sugar, soy, corn, and oil palm - are already in production in industrialised agricultural and agroforestry systems, and thus their development patterns offer valuable insights into the likely economic dynamics of even more production. $^{9}$

\section{a. The intersection of global and agrarian political economy}

Agrarian political economy approaches focus on explaining agrarian change through the lenses of class struggles, peasant differentiation, scale and integration of production, and economic transitions (Borras 2009). ${ }^{10}$ Our analysis aims, in part, to add dynamic international and institutional dimensions to these class-based structural analyses. It supplements agrarian political economy research by focusing on the impact of state relations with MNCs and other

\footnotetext{
${ }^{9}$ Similarly, in the specific case of Brazil, Novo et al. (in this volume) find that sugarcane-based biofuel production is usefully understood 'in the context of the dynamics of other agricultural sectors', including dairy farming and beef production.

${ }^{10}$ For recent discussions of agrarian political economy, see, for example, Bernstein (2009) and Akram-Lodhi (2007). For other work adopting an agrarian political economy framework for analysis, see Martins (2002), Gropas (2006), and Saikia (2008).
} 
states, and the role of comparative advantages in production, along with relations between capital holders and labourers. ${ }^{11}$

The economic and social differentiation of the peasantry - of particular concern to scholars working in the tradition of agrarian political economy (Borras 2009) - interacts with, and is affected by, the opportunities states seize in the international arena; these opportunities are, in turn, mediated by state institutions and state-society relations. Integrating class relations and processes of uneven accumulation into global political economy analyses helps to explain how 'the exploitation of the rural poor [is] intensified through linked credit, labour and commodity markets' (da Corta 2008, 2), particularly as the energy sector intersects with the international food regime described by McMichael (2009).

Using contextualised analyses of state-society and state-corporate relationships, and comparing existing, related sectors, we can develop useful explanations of the patterns observed in the case of biofuels. The political dynamics within biofuel alliances, discussed in the previous section, illustrate the need to consider a 'plurality of authority domains' (Amin and Palan 2001, 568), in which states, MNCs, local communities, and activist networks are engaged in material, discursive, and symbolic struggles over power. As described by Amin and Palan (2001), this critical, or 'non-rationalist', global political economy assumes that state systems are historically situated and transitory, state-market relations are a form of power struggle, and institutions reproduce and reinforce truth and rationality.

Adopting for the moment the framework of a unitary state, we observe variation in the timing and outcomes of entry of states into the biofuel market, with Brazil, India, and Indonesia representing major developing country leaders in sugarcane, Jatropha, and oil palm, respectively. These leaders were already emerging prior to the surge in interest in biofuels. A series of interacting characteristics seem to contribute to their success, particularly their bureaucratic capacity in agricultural and forestry production, the timing of their adoption of biofuel technology and investment in biofuel research and development, and the size of their domestic markets.

\footnotetext{
${ }^{11}$ This is, in many ways, similar to the approach taken in work on the concept of a 'food regime', which considers local food production and distinct food commodity crops in the context of the global political economy. See McMichael (2009) for a genealogy of the food regime analytic approach.
} 


\section{b. State size, development levels, and timing}

Krasner (1976) argues that while all states benefit in terms of national incomes from open trade, small states tend to gain higher relative benefits from such arrangements because a higher proportion of their economies lie within the international system. He adds the caveat, though, that they are therefore more vulnerable to fluctuations in international markets, and have less political power given they bear higher costs from a market closure. In Krasner's account, small developed states can more readily buffer the social instability of open trade than small developing ones, because skilled labour is more easily shifted into other sectors than unskilled labour. Large states, with proportionally larger domestic markets, have less need to buffer their economies from the international market, although large, developed states do have the advantage over large, undeveloped ones of being able to invest in research and development to offset the loss of technological advantages as trading partners gain new technology through market exchanges.

Krasner's argument transfers helpfully to understanding biofuels and other agroforestry commodity markets, where more insulated economies (with larger domestic consumer bases) buffer the uncertainty of international biofuel markets. While the international market may be highly volatile, internal markets in large countries may be more stable, particularly for commodities with multiple uses: sugarcane, soy, and palm oil, for example, are not only of use for biofuel production but also in food production, and, currently, much of the consumption of biofuels is domestic. Countries with small domestic markets rely more on international trade, and may also have a less flexible processing infrastructure to allow producers to shift quickly from biofuels to food commodities. Consequently, Brazil, India, and Indonesia, for instance, may be better positioned through their existing levels of development and size of their domestic markets to take the risks of early entry into the biofuel sector.

Moreover, internationally, Brazil and India already have prominent roles in developing and promoting biofuels. More recent entrants, representing various degrees of investment and interest in biofuels, include Indonesia, Malaysia, Cambodia, Mozambique, Tanzania, and the Democratic Republic of Congo (DRC). From a timing perspective, their late entry affords 
producers in these states access to already-available biofuel technology and potential investors. As noted, some may have the ability to extend already-established food crop production into the fuel sector, as Mathews and Goldsztein (2009) document for soy in Argentina where the highly developed existing agricultural sector can be extended and adapted to new processed outputs and where the existence of multiple markets for the crops buffers against price fluctuations for any single commodity.

However, although there may be latecomer advantages for some states, these late joiners are now participating in a sector dominated by MNCs and integrated into mass-scale production systems, where, for instance, over US\$1 billion in FDI was poured into sugar ethanol production in five African states between 2007 and 2009 (Richardson in this volume), with corporate involvement including British, Brazilian, and French companies, and, equally, the USbased Cargill is a lead exporter of raw sugar and soybeans from Brazil (Holt-Giménez and Shattuck 2009). This operational environment may be difficult to navigate for countries that do not have already well established industrial-scale production of feedstock crops. Consequently, from a state-control perspective, Brazil, India, and Argentina have significant advantages over their less-developed Southern counterparts, with large domestic markets and either having already established a strong state role in developing biofuels prior to the surge in the industry or having alternate established markets for the crops. Additionally, the capacity to adopt new technologies and promote new industrial sectors is influenced not only by size, timing, and the development levels of states, but also by the bureaucratic structures already in place. ${ }^{12}$

\section{c. Grafting new commodities to existing markets: state strength, institutions, and technology adoption}

International market opportunities interact with national institutions, state capacities, and state-society relations in ways that produce different outcomes across countries. Migdal (1988, 277 ) identifies the interaction between states and societies as a key determinant of state

\footnotetext{
${ }^{12}$ A caveat should be added, though, that at the state level, immediate economic gains may not translate into longterm benefits. Richardson (in this volume) cautions (in the context of biofuels from sugarcane in least developed countries in southern Africa) 'in terms of countries trading their way out of poverty, then, while static gains may immediately result for the national GDP [gross domestic product], the more beneficial - and pro-poor - dynamic gains may ultimately be sacrificed'.
} 
strength and governance capacity, expressing doubt about the possibility of changing the structural relations between states and societies (to create a strong state with the capacity to control societal behaviour, for instance) through 'new policies, management techniques, administrative tinkerings, [or] more committed bureaucrats'. Similarly, Putnam (1993) cautions that institutional reform alone cannot produce political change, as bureaucratic and governance structures interact with social and political relationships already in place, producing distinct outcomes. This suggests that an analysis of only state institutions - or only societal and withinstate class relations - is unlikely to explain fully the different trajectories of biofuel development across states. The interaction between institutions and societal organisation and relations is critical for an understanding of the ability of states, at the national level, to take advantage of economic opportunities, such as the development of biofuels.

State strength, involving the 'ability of state leaders to use the agencies of the state to get people in the society to do what they want them to do' (Migdal 1988, xiii), involves the dominance of central states over local strongmen in control of the appropriation and extraction of resources, along with the ability of the state to penetrate society and regulate social relationships. States are more likely to be able to take advantage of international market opportunities when they have the capacity to regulate domestic production. We might, therefore, anticipate that strong states (with established bureaucratic and coercive capacities) will be able to benefit from biofuels more readily than weak or fragmented states. Dauvergne (1998a) qualifies Migdal's analytic framework, however, suggesting that states may have differential strength and control across sectors; for example, states may have control over some aspects of governance, in spite of losing control to local strongmen in the forestry sector. Consequently, states with strength in the agricultural or forestry sectors (depending on the commodity crop) should be expected to benefit (at the national level, although not consistently at the individual farmer level) from expanding global biofuel demand, while states without such sectoral control may struggle to accrue these benefits.

As with the relationships Evans (1995) describes in the information technology sector, where the influence of local firms in partnerships with MNCs diminishes over time, we suggest that - rather than the equitable partnerships envisioned in optimistic appraisals of biofuel 
development - these alliances are likely to increase MNC control over the biofuel sector. In Evans' model, the capacity of states to regulate private sector partnerships is initially strong, but tends to weaken over time as local firms trade up protection by the state in exchange for greater access to the technology and capital of their multinational partners. While many of the corporate and state alliances for biofuels are new, we might anticipate similar patterns given the extent of transnational corporate control over the agrifood and forestry sectors. This corporate control is documented across agricultural crops, with, for example Holt-Giménez and Shattuck (2009) reporting that ADM and Cargill control 75\% of the global grain trade, and McMichael (2009) noting these same firms' roles in the production of corn in Mexico. The shift from public to private ownership and control has also been observed in Indonesia, with McCarthy and Cramb (2009) documenting that by $2006,79 \%$ of oil palm production was from private estates (compared to predominantly state-led production in the 1980s). Evans identifies embedded autonomy as a guard against the loss of state control, where strong networks among government officials and private sector industrialists - combined with corporate coherence and state independence from patrimonial relations - lead to the ability of states to maintain regulatory control over these domestic-international partnerships. This embeddedness does not guard against inequalities within the state, but does make state-level benefits from industrial activities more likely.

Evans describes networks of state-society relations that operate as institutions that shape the trajectory of economic development. Similarly, Vandergeest and Peluso (2006a, 2006b) demonstrate the role existing institutions can play in the constitution of forestry regimes, by examining how the characteristics of professional forestry empires 'were specific to particular colonies and technically uncolonised regions' (2006b, 359), based on the interaction between colonial and local systems. Peluso (1996) provides specific examples of these interactions, outlining the differing social and economic relations of Dayak communities with durian versus rubber cultivation, where the former has an extensive set of social expectations and traditions associated with ownership and shared property rights, while the latter has no such history. Peluso $(1996,537)$ explains that 'not all species have equal significance in the economy or social fabric' of the society. Institutions of land ownership rights interact with the 
kinds of production strategies needed for different biofuel feedstocks, and shape economic opportunities and outcomes.

Sugar, for instance, is costly to establish, and thus is economically most efficient at large plantation-scales (Richardson in this volume), while Jatropha can more readily be produced through outgrower schemes as it is less capital intensive (Arndt et al. 2009). Consequently, biodiesel from Jatropha is more likely (though not certain) to be more pro-poor than bioethanol from sugar, as it can more easily be produced by small-scale farmers (Arndt et al. 2009). ${ }^{13}$ Acemoglu and Robinson $(2009,679)$ argue that 'institutions are a powerful and autonomous force, not simply an adaptation to preexisting (or autonomously evolved) technological conditions. They shape - as much as they are shaped by - the technological trajectory of societies'. Social institutions of property rights, for example, help to explain patterns of technology development, wealth accumulation, and generationally-repeated economic inequality; they intersect with political ecology to contribute to 'the strikingly divergent trajectories of modern nations in an age where technology is largely global and is available for those who wish to adopt it' (Acemoglu and Robinson 2009, 679). Given the global opportunities for biofuels from a number of feedstock crops, these institutional arguments provide insights into the different benefits realised by different developing states.

\section{d. Benefiting from biofuels: decentralisation, embedded autonomy, and predation}

Decentralisation and state fragmentation have some similarities, although the former is not necessarily a signal of the latter. McCarthy $(2007,97)$ argues that 'participation through decentralisation has become a policy tool to make the state more responsive and more adaptable to regional and local needs'. While this might seem close to Migdal's (1988) politics of accommodation, whereby states cede control to local strongmen for fear of being overthrown and lacking the coercive or administrative capacity to maintain control, McCarthy suggests that decentralisation can actually make states ‘more locally legitimate’ $(2007,97)$.

\footnotetext{
${ }^{13}$ However, the potential for small-scale production does not necessitate its production at small scales: Jatropha can also be produced as a large-scale monocrop (see Achten et al. 2010 for a discussion of the potential benefits and concerns of this feedstock), and may in some places be emerging as a crop for wealthy rather than poor farmers (see Ariza-Montobbio et al. in this volume for an analysis of Jatropha production in India).
} 
Rather than reducing state oversight, decentralisation can make central state governance more stable. The trajectory of increased legitimacy rather than usurped control connects to Evans' model of embedded autonomy, where situations with semi-autonomous governments with close network ties to capital-holding elites are more readily incorporated into a legitimacy-enhancing decentralisation, where states without such social ties - or with social ties absent professionalised bureaucracies - are more likely to end up fragmented.

Where state-society bargains of legitimacy based on decentralisation or embedded autonomy have not been struck, or are disrupted by political instability or other shocks, states may face incentives to act as predators of the financial rewards of citizens' activities, and citizens might turn to self-protection from the state (see Bates 2008). Rather than states accumulating national rewards from industrial production and trade, the benefits - if realised at all - will be taken by private producers.

Consequently, while some developing country governments - such as Brazil, India, and Malaysia - might benefit significantly from the economic opportunities from biofuels, late-entry states with less coherent, autonomous bureaucracies and with weak ties between the state and domestic elites are more vulnerable to MNC interests, as the 'new alliance of local entrepreneurs and transnational corporations make it harder to sustain the old alliance between local capital and the state' (Evans 1995, 16). States confronting political instability may likewise lose control of state-level benefits, as they turn to short-term predation at the expense of longer-term gains. This loss of control in the partnerships distances states from the process of governing these industries, thereby compromising their ability, as a state, to reap the rewards of biofuel-driven economic growth.

Additionally, corporate control of industrial development can have significant social and environmental implications, as states lose the power to uphold standards. Since soy and oil palm are two major or incipient biofuel feedstocks in developing countries - notably Brazil, Indonesia, and Malaysia - we can look to existing control of these sectors to provide clues about the likely outcomes of corporate control over the biofuel sector.

\section{e. Corporate power in the agrifood sector and the buffering capacity of CSR}


Clapp and Fuchs (2009), examining the political organisation of what they call the 'agrifood' system, reveal a high concentration of corporate control over the processes of agricultural and food production and distribution. Globally, the top ten food retailers control nearly one-quarter of the food retail market. The top ten seed companies control half of the agrifood seed market. And the top ten pest companies control 84 percent of their market.

Holt-Giménez (2007) identifies a similar pattern of increasing concentration of power in the biofuel industry, documenting an 800 percent increase in venture capital in this sector from 2004-2007, mostly by MNCs. In related agricultural and energy industries, he notes that Cargill and Archer Daniels Midland (ADM) control 65 percent of the global grain trade, while Monsanto and Syngenta control one-quarter of the gene tech industry. Holt-Giménez (2007) argues that MNCs are consolidating control within the value chain of production and that already 'capitalization and concentration of power within the biofuel industry is extreme'. He further maintains that these activities are forcing small landholders out of markets and off land, and that although we could imagine that landholders might be able to consolidate activities rather than exit the market, the increasing concentration of corporate power runs counter to the maintenance of small-scale production.

As corporate control increases and state regulatory capacity decreases in many industries, corporations have responded to civil society pressure for equitable and sustainable practices by developing corporate social responsibility initiatives. Structures are in place, for example, for multi-stakeholder programs for sustainability in soy and palm oil, including the Roundtable on Sustainable Palm Oil (RSPO 2009) and the Round Table on Responsible Soy (RTRS 2009). ${ }^{14}$ These initiatives focus on the environmental and social impacts of the industries. However, according to analyses compiled by Utting and Clapp (2008), in general, private-sector voluntary programs have not proven particularly effective in regulating activities across transnational corporations. Oversight and implementation of CSR have tended to be weak, particularly in the absence of sanctions for non-compliance (Ibid, 27). In addition, only a small percentage of MNCs, affiliates, and suppliers have adopted CSR principles (Ibid, 11).

\footnotetext{
${ }^{14}$ The Round Table on Responsible Soy Association involves multiple stakeholders at the international level; specific regional initiatives also exist, such as the efforts of Dutch corporations to promote sustainable soy through the Task Force Sustainable Soy (TFSS 2009).
} 
Although some legal mechanisms have emerged to try to hold MNCs more accountable in the areas of environmental and social justice, these corporations have highly skilled legal advisors and defense teams (Ibid, 119).

Given Utting and Clapp's analysis, along with articles by other contributing authors in their edited book, the extension of the roundtable model to biofuels - with, for example, the initiation of the Roundtable on Sustainable Biofuels in 2007 - and its continuance in biofuel feedstock sectors (soy and oil palm) would seem to hold only modest potential to advance more equitable and ecologically sound outcomes for the biofuel sector. Consumer pressures for sustainable biofuels might also influence MNCs to behave more sustainably. Yet strong MNC control of the industry without strong state oversight would not suggest this optimistic outcome is likely. In light of the already-concentrated power of MNCs in the agrifood sector, and the limitations of voluntarism in sustainability initiatives, public-private and localmultinational alliances for biofuel production seem far more likely to further entrench corporate control of the processes of production and distribution, and lead to further environmental degradation and social inequities.

At a state level, then, emerging economies with established links to the global market and supportive economic institutions may benefit economically from growth in the biofuel sector; however, these benefits do not extend to all developing countries with feedstock production potential, particularly those entering the market late, with weak bureaucratic structures, and with few channels for societal interests to influence governance decisions. Embedded autonomy, in Evans' account, focuses on societal elites (although he notes the broader social welfare benefits of states with broader social ties); for successful developmental states, this raises the question of the distributional consequences of such state-encouraged industrial activity. Petras and Veltmeyer $(2007,372)$ point out that the 'capitalist state ... necessarily operates in the interests of capital', rather than the interests of society as a whole. In addition to the rising inequalities among developing states, we must also consider the dynamics within the emerging economies that appear to be winners on the global biofuel stage.

\section{Within the state - forest peoples, land tenure, and plantation-based biofuel production}


In addition to state-level variation and inequalities, intrastate dynamics are also shaping the social and environmental impacts of the emerging global biofuel industry. Discussions of sustainability for biofuels tend to focus on the consequences for small-scale landholders, food security, and net carbon emissions across biofuel feedstocks. Even when including biodiversity protection and land use conversion, discussions do not tend to highlight the role of land tenure, non-agricultural forest communities, or the indirect deforestation resulting from displacing communities onto marginal lands. As a result, even if governments and local companies can secure meaningful roles in alliances with multinational corporations, and even if MNCs take CSR seriously, the potential impacts of so-called sustainable biofuel production are still concerning. In light of our analysis of state size, timing, bureaucratic strength, and international market access for agricultural commodities, we might anticipate that countries like Brazil will achieve at least some of the proposed benefits of biofuel development. At the aggregate level this does seem to be occurring. Arndt et al. (2009) present projected benefits from biofuel investment in Mozambique indicating the current trajectory will lead to an increase of $0.6 \%$ in annual national economic growth and a $6 \%$ reduction in poverty over a 12 -year period. National economic growth and corporate profits, of course, do not translate directly or easily to equitable development within a country, especially among diverse social groups. The distribution of benefits depends in large part on sub-national political dynamics. In this section we assess state-societal relations, focusing on differentiating sub-national communities, to shed further light on which groups are especially vulnerable to expanding biofuel production.

Making a case for the need to embed analysis within specific historical contexts, Taylor and Garcia-Barrios (1995) argue that 'globalized and uniformitarian aggregate analyses' are insufficient for assessing the dynamics of environmental change in developing countries. They consider how local conditions intersect with processes in the broader political economy. In particular, they highlight the structures and policies that influence patterns of discrimination against the rural poor, such as educational opportunities and land tenure systems. We focus our analysis on the latter.

Taylor and Garcia-Barrios' model gives particular weight to historical patterns in causal explanations; specifically, it aims to integrate regional-specific studies into generalised causal 
patterns. To better assess the impact of the biofuel industry on rural populations, we use this local-global framework to explore how patterns of land exclusion and conflicting land rights claims intersect with increasing pressure on land from agricultural and forestry-based biofuel feedstocks. We consequently consider 'the economic dimensions of environmental degradation' (Taylor and Garcia-Barrios 1995, 24), as well as the social dimensions of these dynamics. We begin by assessing the ecological trade-offs of producing biofuel feedstock, then turn to reflect on likely socio-ecological implications and outcomes of increasing biofuel production, in light of differentiated groups of rural agrarian and forest communities.

\section{a. Ecological impacts: carbon, biodiversity, and biofuel trade-offs}

Using biofuels as a strategy to mitigate climate change and promote development runs up against other efforts to link climate change mitigation with development, such as programs like reducing emissions from deforestation and forest degradation plus conservation in developing countries (REDD-plus). REDD-plus initiatives, spearheaded by countries like Papua New Guinea under the UN Framework Convention on Climate Change (UNFCCC), compensate developing countries financially for sequestering carbon. In relation to biofuels, though, Kirschbaum (2003) stresses the difficulty of simultaneously managing a forest for both carbon storage and fuel, arguing that storing carbon in temporary sinks is unlikely to have much value for mitigating climate change. He highlights the complexity of the trade-offs involved in forest plantations, noting the lower capacity of younger plantation forests to control erosion, buffer wind, stabilise slopes, and store carbon than older natural forests (although he also points out the higher risk of forest fires in older stands). He also stresses the importance of management for the potential of plantations to store carbon.

Similarly, Gibbs et al. (2008) emphasise the location-specific impacts of plantation crops, where, for example, expanding biofuel feedstock plantations into degraded or alreadycultivated areas provide carbon savings, yet developing them in areas that once held tropical forests provides 'no meaningful carbon benefits', and in fact will likely lead to net carbon emissions. They raise concerns about the risk of expanding agricultural lands, noting that the past two decades have already seen tropical forests cleared for soy and oil palm production. 
Reaffirming these concerns, Danielsen et al. (2009) point out that oil palm has already replaced over 13 million hectares of tropical forests (either directly or indirectly), largely in Southeast Asia, while Norris et al. (2010) conclude that agricultural expansion largely caused the loss of 10 million hectares of forest in West Africa over the last century. An analysis by DeFries et al. (2010) indicates a link between forest loss and the international demand for agricultural products in the 2000-2005 period, which suggests that international agricultural trade may exacerbate deforestation pressures in developing countries, and Trivedi et al. (2009) warn that the interacting pressures of deforestation, biodiversity and ecosystem service loss, and climate change could lead to the loss of half of the Amazonian forest area by 2030. Danielsen et al. (2009) note the irony that efforts to meet Kyoto Protocol carbon reduction commitments through biofuels may actually speed up climate change through carbon releases from forest conversion, and may additionally undermine other environmental commitments, including the Convention on Biological Diversity.

Turning from the more ecological to social impacts (although we acknowledge that these are interrelated, particularly given both the social causes and the impacts on communities of environmental degradation), we observe equally complex trade-offs where the benefits and costs of biofuel production vary across places, biofuel feedstock crop types, and social groups.

\section{b. Social and economic impacts: histories of displacement}

\section{1) State-society relations}

Biofuel production has contributed to land use and land tenure conflicts in some rural areas. ${ }^{15}$ One way to examine such conflicts over land use is to compare state versus community control of production systems. In an analysis of community forestry and 'domestic forests', Michon et al. (2007) describe the knowledge by local farmers of forest management. They advocate for more equitable relations between forest agency 'experts' and farmers managing forest resources on their own land. Recognizing and respecting community expertise, Michon et al.

\footnotetext{
${ }^{15}$ See McMichael (in this volume) for an analysis of the meaning and consequences of this 'global land grab' and of the intensification of 'a long-term process of appropriation of resources by powerful states and firms'.
} 
optimistically argue, would help promote sustainable coexistence of people and nature (and help to avoid a trade-off between development and conservation).

Their analysis is based on states and society as the relevant divide in forest management. This may not reveal, however, the full picture of competing knowledges and practices in local ecosystem governance. State-society and rural-urban dichotomies are often insufficient for describing the interests of groups within a country. Mitchell's (1991) critique of the state-society divide is helpful for structuring a more complex understanding of power relations, particularly in the context of emerging alliances of local firms, governments, and MNCs. These alliances blur the line between states and certain economic groups within the state; sustainability initiatives that involve civil society also illustrate the divides within 'society', as social groupings often do not represent all - or even most - peoples' interests.

The idea of societal disaggregation, and especially peasant differentiation, has a robust place in the agrarian political economy literature, with Byres (2009), for example, tracing the history of the stratification of peasant communities in different national settings. As defined by Wright $(2006,144)$, class exploitation involves not only asymmetric access to productive resources (which he describes as 'nonexploitative economic oppression'), but also the appropriation of the products of the labour of the exploited by those who control the resources. Specifically, the link between property relations and exploitation is based on ongoing interactions and depends on the efforts of the exploited. Wright reveals multiple dimensions of class relations, along continuums of authority, skill levels, ownership of means of production, and the engagement of paid labour. Such distinctions make it difficult to undertake a simple class analysis based on 'proletariat' and 'bourgeoisie', but reflect important subtle differences among groups of small-holder and subsistence-level rural people. Byres $(2009,35)$ identifies peasants through their ties to the land, coerced relinquishing of rents, and 'servile' position in domestic production systems, where peasants have a similar structural position in the economy, but he emphasises 'it is crucial to note that these peasantries are socially differentiated'.

Da Corta (2008) similarly notes the structural position of peasants, highlighting their assets-based vulnerability, in which they often face resource trade-offs, and the sacrifice of 
long-term stability to solve short-term problems. These economic dilemmas are, according to da Corta $(2008,6)$, rooted in 'deeply unequal social relations', and have a somewhat pathdependent trajectory, in which those with some material and social advantages benefit from, and can manufacture opportunities for, accumulation during times of economic changes and crises. These dynamics have been seen in the past with the introduction of new technologies and practices; for instance, Scott (1987) documents the impacts of combines and doublecropping on the material and social conditions of different peasant groups in a village in Malaysia. Shifts in global markets and opportunities - such as the surge in interest in biofuels therefore intersect with local social relations, tending to yield the greatest benefits to more privileged groups and further entrenching the vulnerability of poor people.

Thus, for understanding the potential consequences of biofuels, divides among and within social groups are as relevant as divides between the state and society. Mitchell (1991, 77) argues that the boundary between the state and society is 'elusive, porous, and mobile', indicating the importance of assessing the patterns of organisation and control - and exclusion - that emerge in different configurations of power relations. Disaggregating more highly commercialised agrarian households from predominantly subsistence-level farmers, and more agrarian from more forest-dependent people, ${ }^{16}$ provides useful insights into the impacts of biofuels; it also illustrates the variable economic benefits likely to accrue to different people even in countries with effective governments. Developing biofuels, for example, may well benefit some impoverished rural groups, while further harming others.

\section{2) Land tenure conflicts and socio-ecological impacts of historical patterns of exclusion}

At the state level, benefits accrued from biofuels depend, to some extent, on the interaction among existing governance institutions, and on relationships among producers, industrialists, and the state. These institutions and networks enable some states to adopt new technologies and enter global markets. In the same way, at the subnational level, the existing patterns of wealth, land, and power distribution influence the ability of different groups to share in the benefits of new opportunities. Biofuels have been presented as a way to provide economic

\footnotetext{
${ }^{16}$ Noting, as in footnote 3 , that these categories are not strictly delineated; for instance, landless households may be more dependent on forest products than land-holding households, as Santra et al. (2008) document.
} 
development to small-scale farmers. However, historical legacies of land tenure and control influence the likelihood that rural communities can take advantage of these opportunities. The displacement of communities for extractive industrial activities and for conservation have been observed in the past; Adams and Hutton (2007) describe the displacement of people in Ethiopia and Botswana to establish protected areas; and Meher (2009) examines the displacement of tribal people in India for mining projects. It is not a stretch, therefore, to consider the potential displacement of subsistence farmers, indigenous communities, and other marginalised groups for biofuel development.

Land tenure conflicts involve not only current societal relationships, but emerge out of historical struggles for control. Michon et al. (2007) provide advice for incorporating community forestry into state forestry practices, requiring states to not only recognise the knowledge of local communities, but also their rights to the land and products of the land. However, there are substantial barriers to overcoming these histories; while Michon et al.'s suggestion may be an advisable strategy to improve forest management, it would require major changes in state control of land resources and state relations with marginalised social groups. Beyond accounting for historical state relations with different groups, Shah's (2005) work on the historical displacement and adaptation of the indigenous adivasi people in India underscores the importance of considering societal - and especially peasant - differentiation and relations. Shah (2005) analyses the adivasi peoples' geographic and social disruption by colonial intrusion, finding that marginalisation is not only a product of exclusion by the state, but is also perpetuated and reinforced by other societal groups.

For many rural households, land tenure is by no means secure; thus efforts to integrate even small-scale landowners into production systems still exclude many rural people. These marginalised people tend to have complex relationships with the state and with the ecosystems on which they depend. Lawlor et al. (2009, 6-7), for example, note that in some countries clearing a forest can be a way to establish property rights and demonstrate 'productivity'. Although this may be one avenue for securing land tenure, in the tropics it usually does not promote environmental or long-term economic sustainability, because such property rights 
regimes provide incentives to develop agriculture and plantations at the expense of previously biologically-rich forests.

Beyond the loss of forests from incentives to clear land to secure tenure, displacing and resettling communities into new areas also tends to increase pressure on forests. Tropp (2003, 213), for example, finds that the displacement of indigenous people in the South African region of Transkeian contributed to more conflict over land and increased the intensity of forest resource use by the transplanted communities, as they constructed new settlements. Moreover, the patterns of resettlement established during colonial times influenced indigenous communities' relations with the state in the post-colonial era, providing the basis for both extensive state intervention and competing narratives by indigenous people on conservation and development.

Along with the increased segmentation of rural communities resulting from uneven effects on forest-based and agricultural households, there may be uneven impacts within agrarian communities. First, there may be layered levels of ownership of (and access to) land and forest resources that do not correspond to official property rights, which corporate management of biofuel feedstock production can damage. For instance, Rocheleau and Edmunds $(1997,1351)$ describe the gendered dynamics of property rights over trees, particularly in Africa, which involve 'nested and overlapping rights'. These rights may be negotiable within the community, and difficult to manage when external ownership and production regimes are fixed rather than flexible. ${ }^{17}$ The lack of tenure has proven detrimental for poor households' participation in other sustainable development initiatives, too. Boyd et al. (2007), for example, examine Clean Development Mechanism (CDM) carbon sink projects under the UNFCCC, finding that the projects tend to exclude those without nationally recognized and sanctioned land ownership - people who tend to be the poorest.

Second, differential access to land and capital may influence farmers' abilities to invest in different crops. Biofuel production may provide opportunities for high economic returns for some farmers, as, for example, McCarthy and Zen (2010) report happened when the price of

\footnotetext{
${ }^{17}$ In the context of biofuels, see Julia and White (in this volume) for an analysis of the impacts of oil palm expansion on a Hibun Dayak community in Indonesia, disaggregated by gender. Additionally, for a more general discussion of gender in agrarian political economy, see Razavi (2009).
} 
palm oil went from $\$ 570$ to more than $\$ 1440$ per metric ton from 2007 to 2008 , and as Richardson (in this volume) documents when the world price for sugar reached a 30-year high in August 2009. However, potential returns can vary widely across biofuel feedstock crops, and may prove polarising as land- and capital-poor community members find themselves unable to capitalise on these opportunities. In terms of variation across feedstocks, Jatropha, for example, is estimated to be twice as land intensive as sugar for biofuels, but sugar is three times more capital intensive (Arndt et al. 2009). Consequently, farmers with greater initial access to capital can invest in sugarcane crops that have a higher return per unit of land, while those lacking such funds may be excluded from these opportunities.

Third, the role of risk in biofuel production is relevant to this unevenness within agrarian communities. Despite high prices for palm oil and sugar, McCarthy and Zen (2010) and Richardson (in this volume) note the volatility of these commodity prices. Although at various times returns from some crops may be high, farmers may be faced with bearing the costs of failed efforts, and those already living at the margins can find themselves unable to take such risks. Scott (1976), in The Moral Economy of the Peasant, highlights the trade-offs subsistence farmers face between economic returns and risk aversion, where higher financial rewards are foregone in favour of less risky investments for those who have little capacity to buffer losses. Although some econometric studies challenge these assumptions of risk-aversion by poor farmers (see, for instance, Henrich and McElreath 2002, and Roumasset 2008), several studies provide evidence that low-income households allocate greater financial and labour resources to low-risk, low-return crops (see Vargas Hill 2009 for a brief survey and an analysis of Ugandan coffee production). Wegren (2008) demonstrates the impact of economic status on riskaversion in Russia, suggesting the need for a differentiated assessment of decision making based on risk-taking tendencies. Nelson and Galvez (2000) assess the social impacts of the cocoa industry, and caution that, even with fair trade schemes, agricultural production that focuses on a single commodity pose many dangers. A single-crop focus, for example, can increase the risk for producers who give up diversified investment activities; it can also marginalise the most vulnerable producers without liquid assets and reserve funds who are unable to reduce diversity and therefore cannot take advantage of market openings. 


\section{Unlikely positive agriculture-industry synergies for biofuels}

Many researchers have reflected on possible strategies for more sustainable biofuel production, with solutions ranging from the use of alternate (and especially non-food) feedstocks (e.g., Regalbuto 2009), to fostering synergies between agriculture and industry (e.g., Kay 2009), to promoting more open and extensive North-South trade (e.g., Mathews 2007). However, although these initiatives address some of the trade-offs among food security, energy security, and biodiversity protection - the trilemma, in Tilman et al.'s (2009) description - for landless and non-agrarian rural peoples these do not solve, and may even exacerbate, the problems that industrial and globalised biofuel production cause for land rights and land tenure.

Some policies and actions for renewable energy have the potential to benefit smallscale farmers, promote second- and third-generation biofuels, and encourage the use of marginal lands rather than food-producing agricultural fields for biofuel feedstocks. Replacing mixed forests with oil palm plantations (replacing forests with plantations, preventing net deforestation) and of marginal cropland with Jatropha and switchgrasses (turning unproductive areas, rather than agricultural fields, into feedstock production lands), may reduce the impact on food crops and the direct carbon footprint of resulting biofuels. Although plantation forests rarely, if ever, replicate the ecological and biological value of natural forests, they can provide some ecological benefits, which vary depending on the extent to which they are monocultures, introduce exotic and invasive species, and have variation in their understories (Rudel et al. 2005).

Regalbuto (2009) considers the potential for woody biomass-based biofuels, which would reduce concerns about food being used for fuel. Tilman et al.'s $(2009,271)$ trilemma of food, energy, and environment addresses the trade-offs between agricultural land and food production, greenhouse gas reductions, and biodiversity. In response to these challenges, they advise that 'Three steps should be taken: meaningful science-based environmental safeguards should be adopted, a robust biofuel industry should be enabled, and those who have invested in first-generation biofuels should have a viable path forward'. 
However, the failure of some fair trade systems to protect the livelihoods of the most vulnerable people, as Nelson and Galvez (2000) document, raises concerns about the ability of sustainability initiatives in the biofuel sector to protect environmental and social well-being. Even though some sustainability pathways for biofuels consider food and fuel, many still leave out questions of land use conversion from intact or diverse standing forests, as well as questions of land rights of resident communities that increased production may displace. The indirect effects of promoting biofuels may therefore still prove to be ecologically and socially destructive, and undermine the optimistic projections of combining economic development with social equality and environmental protection. Such sustainability measures, if they ignore contentious land tenure claims and historical patterns of exclusion, are unlikely to prevent the further displacement of communities from marginal lands.

Steward's (2007) critical analysis of 'sustainable soy' in Brazil, for instance, points to the differing ways actors and stakeholders interpret forest use and sustainable practices. Conservation NGOs, agricultural firms, and the state have different views, for example, on forest values and appropriate use than do local small-scale farmers (or 'colonos'). As Tropp (2003) discovered in South Africa, Steward finds that current land use practices and relations are a product of the area's settlement history, and the legacy of colonial control over land. The dominant state and mainstream NGO discourses on development, she argues, denies the role of local farmers in sustaining and promoting ecological diversity and ignores the matrix of agricultural land and secondary forests that they maintain. These farmers' consequent exclusion from development plans further entrenches poverty within these communities.

These dynamics of deforestation and environmental protection further illustrate the complexity of displaced and marginalised peoples' relationships with the forests, the state, and within society. Lawlor et al. (2009) highlight this complexity for mitigating climate change. Analyzing the reduction of emissions from deforestation and land degradation, they find, in addition to insecure property rights for forest people, many problems with the proposed emissions reduction programs and payments for avoided deforestation, including limited public participation in forest and revenue management, and corruption. These potential problems 
both parallel and augment the ones in the biofuel sector, undermining efforts to promote socially and environmentally sustainable biofuels.

Competing discourses around biofuel development now contest the meanings of sustainable biofuels, although generally these debates are framed in terms of food security and opportunities for small-scale landowners, but not in the broader context of land rights and indigenous peoples' displacement. With a history of antagonistic relations between many states and 'their' indigenous peoples, the new alliances among public and private investors and producers of biofuels, especially between MNCs and governments and local firms in the global South, thus seem poised to reinforce patterns of exclusion and marginalisation rather than achieve any lasting environmental and social gains.

\section{Conclusions}

MNCs, as the trajectory of the emerging global biofuel industry shows, are poised to increase their control over the next few years over the production and distribution of biofuels, particularly from major feedstocks like corn, sugarcane, soy, and oil palm. The histories of the global political economies of related agriculture, energy, and forestry sectors suggest this is likely, especially given the consolidation of control over the production and export of these feedstock crops by agricultural MNCs like ADM, Cargill, and others. If the biofuel industry does follow the path of these sectors, states with weak bureaucratic capacity look set to lose control of partnerships between local firms and MNCs, further entrenching the power of MNCs in the agrifood, forestry, and energy sectors. In the absence of state oversight, voluntary measures seem unlikely to realise the positive potential of biofuels, especially given past failures of CSR to enhance sustainability in the agrifood and forestry sectors. Moreover, even where economic benefits extend beyond MNCs, any benefits will accrue unevenly in rural communities, with small-scale farmers, people with insecure land rights, and - especially - indigenous forest peoples largely left out or even harmed, particularly by industrial-scale and plantation-based production of feedstock crops.

Our analysis of the role of biofuel alliances and coalitions contributes to the theoretical debates in global and agrarian political economy. First, at the state level, our findings suggest 
that aggregate economic benefits from biofuels will more likely accrue to developing countries that enter biofuel markets early and that have existing export-oriented sectors to channel biofuels more effectively into the global market. This will be most easily accomplished with crops already under large-scale production in those countries, like oil palm and sugar, and crops that are efficiently produced through plantation or large monocrop processes. States with large internal markets to buffer against the risks of competing internationally will also benefit more easily. So, too, will states with strong administrative capacity in agrifood, forestry, and energy, as these states will have more opportunities and fewer barriers to taking advantage of global opportunities to develop biofuels. These opportunities are then likely to reinforce the economic and political power of emerging economies of the South.

Second, by highlighting state-society relations, particularly drawing on recent work in agrarian state-society relations, our analysis contributes to understanding the consequences within countries of developing biofuels. We analysed the framing of debates on sustainable biofuels at the domestic level, drawing attention to marginalised communities that state and corporate narratives tend to exclude. We then linked the patterns of exclusion in these relations to histories of displacement and land tenure conflict in forestry and agriculture, particularly through the designation of land as marginal or idle. Although food security is an important dimension of these debates, we have demonstrated that the development of commercial biofuels raises equally critical concerns for land rights, forest access, and nonagrarian livelihoods.

Our findings further add cautionary notes to the sustainability of so-called sustainable biofuels, as well as the value of more open markets for biofuels from the South. Some field studies suggest that some farmers and communities may benefit from the development of new and diversified markets for agricultural commodities and from local energy production. Smallscale production and cooperative efforts, in which farmers maintain control of their crops and land, could well contribute to economic stability and improved livelihoods. However, the increasing corporate control of industrial-scale biofuel production and distribution processes puts into doubt the ability of the sector to achieve widespread positive results for the poor. The distributional consequences of biofuel production appear set to leave behind those states - and 
especially groups within states - that are already at a disadvantage in the international system. The production and consumption patterns of biofuels will benefit, at the international level, states with existing experiences of success in the global economy, and, at the domestic level, groups already integrated into commercial production systems. States and rural and indigenous people already struggling to cope with globalised markets and industrialised production will be left even further behind, with even well-intentioned efforts to mitigate climate change and support development through biofuels likely to accelerate deforestation and further marginalise vulnerable people and ecosystems.

\section{References}

Accenture. 2008. 'Irrational exuberance'? An assessment of how the burgeoning biofuels market can enable high performance: A supply perspective. Accenture Consulting.

Acemoglu, D. and J. Robinson. 2009. Foundations of societal inequality. Science, 326 (30 October), 678679.

Achten, W.M.J., W.H. Maes, R. Aerts, L. Verchot, A. Trabucco, E. Mathijs, V.P. Singh and B. Muys. 2010. Jatropha: From global hype to local opportunity. Journal of Arid Environments, 74(1), 164-165.

Adams, W.M. and J. Hutton. 2007. People, parks and poverty: political ecology and biodiversity conservation. Conservation and Society, 5(2), 147-183.

Akram-Lodhi, A. H. 2007. Land, markets and neoliberal enclosure: an agrarian political economy perspective. Third World Quarterly, 28(8), 1437-1456.

Amin, A. and R. Palan. 2001. Towards a non-rationalist international political economy. Review of International Political Economy, 8(4), 559-577.

Antkiewicz, A. and J. Whalley. 2006. BRICSAM and the non-WTO. Review of International Organizations, 1(3), 237-261.

Ariza-Montobbio, P., S. Lélé, J. Martinez-Alier and G. Kallis. 2010. The political ecology of Jatropha curcas plantations for biodiesel in Tamil Nadu: a socio-ecological failure with uneven consequences. Journal of Peasant Studies, 37(3).

Arndt, C., R. Benfica, F. Tarp, J. Thurlow and R. Uaiene. 2009. Biofuels, poverty, and growth: a computable general equilibrium analysis of Mozambique. Environment and Development Economics, 15, 81-105.

Associated Press (AP). 2008. White House defends food-based biofuels: administration backing decision as food costs rise at home and abroad [online]. MSNBC - Politics, May 19. Available from: http://www.msnbc.msn.com/id/24715112/ [Accessed 30 August 2009].

Bates, R. 2008. When things fell apart: state failure in late-century Africa. Cambridge: Cambridge University Press.

Belcher, B. and K. Schreckenberg. 2007. Commercialisation of non-timber forest products: a reality check. Development Policy Review, 25(3), 355-377.

Bernstein, H. 2009. V.I. Lenin and A.V. Chayanov: looking back, looking forward. Journal of Peasant Studies, 36(1), 55-81.

Borras, Jr., S.M. 2009. Agrarian change and peasant studies: changes, continuities and challenges - an introduction. The Journal of Peasant Studies, 36(1), 5-31. 
Boyd, E., M. Gutierrez and M. Chang. 2007. Small-scale forest carbon projects: Adapting CDM to lowincome communities. Global Environmental Change, 17(2), 250-259.

Broegaard, R.J. 2005. Land tenure insecurity and inequality in Nicaragua. Development and Change, $36(5), 845-864$.

Byres, T.J. 2009. The landlord class, peasant differentiation, class struggle and the transition to capitalism: England, France and Prussia compared. Journal of Peasant Studies, 36(1), 33-54.

Campbell, H. 2008. China in Africa: challenging US global hegemony. Third World Quarterly, 29(1), 89105.

Chakrabortty, A. 2008. Secret report: biofuel caused food crisis - Internal World Bank study delivers blow to plant energy drive [online]. The Guardian, July 4. Available from: http://www.guardian.co.uk/environment/2008/jul/03/biofuels.renewableenergy [Accessed 10 August 2008].

Clapp, J. and D. Fuchs, eds. 2009. Corporate power in global agrifood governance. Cambridge, MA: MIT Press.

Cooper, A.F., A. Antkiewicz and T.M. Shaw. 2007. Lessons from/for BRICSAM about South-North relations at the start of the 21st century: economic size trumps all else? International Studies Review, 9, 673-689.

Da Corta, L. 2008. The political economy of agrarian change: dinosaur or phoenix? Queen Elizabeth House Working Paper Series, QEHWPS174, Working Paper Number 174. University of Oxford.

Danielsen, F., et al. 2009. Biofuels plantations on forested lands: double jeopardy for biodiversity and climate. Conservation Biology, 23(2), 348-358.

Dauvergne, P. 1997. Shadows in the forest: Japan and the politics of timber in Southeast Asia. Cambridge, MA: MIT Press.

Dauvergne, P. 1998a. Weak and strong states in Asia-Pacific societies. Sydney: Allen and Unwin.

Dauvergne, P. 1998b. The political economy of Indonesia's 1997 forest fires. Australian Journal of International Affairs, 52(1), 13-17.

Dauvergne, P. 2001. Loggers and degradation in the Asia-Pacific: corporations and environmental management. Cambridge: Cambridge University Press.

Dauvergne, P. and K.J. Neville. 2009. The changing North-South and South-South political economy of biofuels. Third World Quarterly, 30(6): 1087-1102.

Davis, C. 2007. March 2007 monthly update: global biofuel trends [online]. World Resources Institute, EarthTrends Environmental Information. Available from: http://earthtrends.wri.org/updates/node/180 [Accessed 6 January 2009].

DeFries, R.S., T. Rudel, M. Uriarte and M. Hansen. 2010. Deforestation driven by urban population growth and agricultural trade in the twenty-first century. Nature Geoscience, 3, 178-181.

Donald, P.F. 2004. Biodiversity impacts of some agricultural commodity production systems. Conservation Biology, 18(1), 29.

Evans, P. 1995. Embedded autonomy: states and industrial transformation. Princeton, NJ: Princeton University Press.

Fargione, J., et al. 2008. Land clearing and the biofuel carbon debt. Science, 319(5867), 1235-1238.

Forge, F. 2007. Biofuels - an energy, environmental or agricultural policy? [online]. Library of Parliament, Parliamentary Information and Research Service, Science and Technology Division, 8 February. Available from: http://www.parl.gc.ca/information/library/PRBpubs/prb0637-e.pdf [Accessed 7 January 2009].

Franco, J., L. Goldfarb, M. Hoenicke, M.L. Mendonca and D. Fig. 2010. Interrogating European Union biofuels policy: (drivers, assumptions, visions, and impacts) with case studies from Germany, Brazil and Mozambique. Journal of Peasant Studies, 37(3). 
Gibbs H.K., et al. 2008. Carbon payback times for crop-based biofuel expansion in the tropics: the effects of changing yield and technology [online]. Environmental Research Letters, 3(3). Available from: http://www.iop.org/EJ/article/1748-9326/3/3/034001/erl8_3_034001.html [Accessed 27 August 2009].

Goldemberg, J. 2007. Ethanol for a sustainable energy future. Science, 315(5813), 808-810.

Gropas, M. 2006. Landscape, revolution and property regimes in rural Havana. Journal of Peasant Studies, 33(2), 248-277.

Henrich, J. and R. McElreath. 2002. Are peasants risk-averse decision makers? Current Anthropology, 43(1), 172-181.

Holt-Giménez, E. 2007. Displaced peasants, higher food prices, and a crutch for the petrol industry [online]. Global Policy Forum. Available from: www.globalpolicy.org/component/content/article/212/45389.html [Accessed 27 August 2009].

Holt-Giménez, E. and A. Shattuck. 2009. The agrofuels transition: Restructuring places and spaces in the global food system. Bulletin of Science Technology Society, 29(3), 180-188.

Hunsberger, C. 2010. 'This plant can change lives': Small farmer and other stakeholder perspectives on Jatropha curcas in Kenya. Journal of Peasant Studies, 37(3).

Julia, (Kam) and B. White 2010. Expropriation and incorporation: gendered politics of oil palm expansion in a Dayak Hibun community in West Kalimantan. Journal of Peasant Studies, 37(3).

Kay, C. 2009. Development strategies and rural development: exploring synergies, eradicating poverty. Journal of Peasant Studies, 36(1), 103-137.

Kirschbaum, M.U.F. 2003. To sink or burn? A discussion of the potential contributions of forests to greenhouse gas balances through storing carbon or providing biofuels. Biomass and Bioenergy, 24(45), 297-310.

Krasner, S.D. 1976. State power and the structure of the international trading system. World Politics, 28 (3), 317-43.

Kurdusiewicz, I. and G. Wandesforde-Smith. 2008. Bursting the biofuel bubble: comparative dynamics of transitions to freedom from oil. Conference paper for the 49th Annual Meeting of the International Studies Association, San Francisco, California, 26-29 March 2008.

Lawlor, K., L.P. Olander and E. Weinthal. 2009. Sustaining livelihoods while reducing emissions from deforestation: options for policymakers. Working Paper NI WP 09-02. Nicholas Institute for Environmental Policy Solutions, Duke University.

Lula da Silva, L.I. 2007. Statement of Brazil at the general debate of the 62nd Session of the United Nations General Assembly [online]. New York, September 25. Available from: www.un.org/webcast/ga/62/2007/pdfs/brazil-en.pdf [Accessed 31 August 2009].

Lula da Silva, L.I. 2008. Statement at the FAO high-level conference on world food security: the challenges of climate change and bioenergy. Rome, Italy, June 3.

Martin, W.G. 2008. Africa's futures: from North-South to East-South? Third World Quarterly, 29(2), 339356.

Martins, J. de. S. 2002. Representing the peasantry? Struggles for/about land in Brazil. Journal of Peasant Studies, 29(3), 300-335.

Mathews, J.A. 2007. Biofuels: what a biopact between North and South could achieve. Energy Policy, 35, 3550-3570.

Mathews, J.A. and H. Goldsztein. 2009. Capturing latecomer advantages in the adoption of biofuels: the case of Argentina. Energy Policy, 37, 326-337.

McCarthy, J. 2007. Shifting resource entitlements and governance reform during the agrarian transition in Sumatra, Indonesia. Journal of Legal Pluralism, 55, 95-121.

McCarthy, J. 2010. The oil palm question: biofuels, oil palm and agrarian change in East Sumatra. Journal of Peasant Studies, 37(3). 
McCarthy, J.F. and R.A. Cramb. 2009. Policy narratives, landholder engagement, and oil palm expansion on the Malaysian and Indonesian frontiers. The Geographical Journal, 175(2), 112-123.

McCarthy, J. and Z. Zen. 2010. Regulating the oil palm boom: assessing the effectiveness of environmental governance approaches to agro-industrial pollution in Indonesia. Law \& Policy, 32(1), 153-179.

McMichael, P. 2009. A food regime genealogy. Journal of Peasant Studies, 36(1), 139-169.

McMichael, P. 2010. The priceless nature of agrofuels. Journal of Peasant Studies, 37(3).

Meher, R. 2009. Globalization, displacement and the livelihood issues of tribal and agriculture dependent poor people: the case of mineral-based industries in India. Journal of Developing Societies, 25(4), 457-480.

Michon, G., H. De Foresta, P. Levang and F. Verdeaux. 2007. Domestic forests: a new paradigm for integrating local communities' forestry into tropical forest science [online]. Ecology and Society, 12(2), 1. Available from: http://www.ecologyandsociety.org/vol12/iss2/art1/ [Accessed 27 August 2009].

Migdal, J.S. 1988. Strong societies and weak states: state-society relations and state capabilities in the Third World. Princeton, NJ: Princeton University Press.

Mitchell, T. 1991. The limits of the state: beyond statist approaches and their critics. The American Political Science Review, 85(1), 77-96.

Moreira, J.R., L.A.H. Nogueira and V. Parente. 2005. Biofuels for transport, development, and climate change: Lessons from Brazil, chapter 3 in Growing in the greenhouse: protecting the climate by putting development first [online], K.A. Baumert et al., World Resources Institute. Available from: http://pdf.wri.org/gig_chapter3.pdf [Accessed 30 August 2009].

Nelson, V. and M. Galvez. 2000. Social impact of ethical and conventional cocoa trading on forestdependent people in Ecuador. Natural Resources and Ethical Trade Programme, Natural Resources Institute, University of Greenwich.

Norris, K., A. Asase, B. Collen, J. Gockowksi, J. Mason, B. Phalan and A. Wade. 2010. Biodiversity in a forest-agriculture mosaic: the changing face of West African rainforests. Biological Conservation (in press).

Novo, A., K. Jansen, M. Slingerland and K. Giller. 2010. Biofuel, dairy production and beef in Brazil: competing claims on land use in Sao Paulo state. Journal of Peasant Studies, 37(3).

Parayil, G. and F. Tong. 1998. Pasture-led to logging-led deforestation in the Brazilian Amazon: the dynamics of socio-environmental change. Global Environmental Change, 8(1), 63-79.

Peluso, N.L. 1996. Fruit trees and family trees in an anthropogenic forest: ethics of access, property zones, and environmental change in Indonesia. Comparative Studies in Society and History, 38(3), 510-548.

Peluso, N.L. and P. Vandergeest. 2001. Genealogies of the political forest and customary rights in Indonesia, Malaysia, and Thailand. The Journal of Asian Studies, 60(3), 761-812.

Petras, J. and H. Veltmeyer. 2007. The 'development state' in Latin America: whose development, whose state? Journal of Peasant Studies, 34(3), 371-407.

Pimentel, D. 2003. Ethanol fuels: Energy balance, economics, and environmental impacts are negative. Natural Resources Research, 12(2), 127-134.

Pimentel, D. and T.W. Patzek. 2005. Ethanol production using corn, switchgrass, and wood: biodiesel production using soybean and sunflower. Natural Resources Research, 14(1), 65-76.

Pin Koh, L. and D.S. Wilcove. 2007. Cashing in palm oil for conservation. Nature, 448, 993-994.

Punter, G., et al. 2004. Well-to-wheel evaluation for production of ethanol from wheat [online]. FWG-P04-024, Low Carbon Vehicle Partnership Fuels Working Group, Well To Wheel Sub-Group. Available from: http://www.lowcvp.org.uk/assets/viewpoints/Biofuels\%20WTW\%20final\%20report.pdf [Accessed 31 August 2009]. 
Putnam, R.D. 1993. Making democracy work: civic traditions in modern Italy. Princeton, NJ: Princeton University Press.

Pye, O. 2010. The biofuel connection - transnational activism and the palm oil boom. Journal of Peasant Studies, 37(3).

Roumasset, J. 2008. A new institutional approach to pro-poor agricultural development: lessons from Asia. Journal of Asian Economics, 19, 378-388.

Razavi, S. 2009. Engendering the political economy of agrarian change. Journal of Peasant Studies, 36(1), 197-226.

Regalbuto, J.R. 2009. Cellulosic biofuels - got gasoline? Science, 325, 822-824.

Richardson, B. 2010. Trade and transformation in Southern Africa: a Polanyian reading of sugarcane exports. Journal of Peasant Studies, 37(3).

Righelato, R. and D.V. Spracklen. 2007. Carbon mitigation by biofuels or by saving and restoring forests? Science, 17, 902.

Ringwald, A. 2006. Could sustainable investment in developing countries address Europe's 'biodiesel famine'? Yale School of Forestry and Environmental Studies, Master's Thesis.

Rocheleau, D. and D. Edmunds. 1997. Women, men and trees: gender, power and property in forest and agrarian landscapes. World Development, 25(8), 1351-1371.

Round Table on Responsible Soy (RTRS). 2009. Roundtable on Responsible Soy Association: who we are [online]. Available from: http://www.responsiblesoy.org/ [Accessed 27 August 2009].

Roundtable on Sustainable Palm Oil (RSPO). 2009. Promoting the growth and use of sustainable palm oil [online]. Available from: http://www.rspo.org/ [Accessed 27 August 2009].

Rudel, T.K., et al. 2005. Forest transitions: towards a global understanding of land use change. Global Environmental Change, 15, 23-31.

Saikia, A. 2008. Forest land and peasant struggles in Assam, 2002-2007. Journal of Peasant Studies, 35(1), 39-59.

Santra, A.K., A.K. Samanta and S. Pan. 2008. Forest based economic dependency of farmers in South West Bengal. Environment and Ecology, 26(4), 1598-1601.

Scharlemann, J.P.W. and W.F. Laurance. 2008. How green are biofuels? Science, 319 (5859), 43-44.

Scoones, I. 2009. Livelihoods perspectives and rural development. Journal of Peasant Studies, 36(1), 171196.

Scott, J.C. 1976. The moral economy of the peasant: rebellion and subsistence in Southeast Asia. New Haven: Yale University Press.

Scott, J.C. 1987. Weapons of the weak: everyday forms of peasant resistance. New Haven: Yale University Press.

Shah, M. 2005. First you push them in, then you throw them out. Economic and Political Weekly, November 19, 4895-4899.

Smith, J., K. Obidzinski, Subarudi and I. Suramenggala. 2003. Illegal logging, collusive corruption and fragmented governments in Kalimantan, Indonesia. International Forestry Review, 5(3), 293-302.

Steward, C. 2007. From colonization to "environmental soy": a case study of environmental and socioeconomic valuation in the Amazon soy frontier. Agriculture and Human Values, 24, 107-122.

Sumner, A. 2008. Foreign direct investment in developing countries: have we reached a policy 'tipping point'? Third World Quarterly, 29(2), 239-253.

Supachai, P. 2008. South-South trade [online]. Paper by the Secretary-General of UNCTAD, Istanbul, June 3. Available from: www.developing8.org/2008/06/03/southsouth-trade-paper-by-sg-unctadsecretary [Accessed 7 January 2009].

Task Force Sustainable Soy (TFSS). 2009. The task force sustainable soy [online]. Available from: http://www.taskforcesustainablesoy.org/index.php [Accessed 27 August 2009]. 
Taylor, P. and R. García-Barrios. 1995. The social analysis of ecological change: from systems to intersecting processes. Social Science Information, 34(1), 5-30.

Tilman, D., et al. 2009. Beneficial biofuels - the food, energy, and environment trilemma. Science, 325, 270-271.

Trivedi, M.R., A.W. Mitchell, N. Mardas, C. Parker, J.E. Watson and A.D. Nobre. 2009. REDD and PINC: A new policy framework to fund tropical forests as global 'eco-utilities'. IOP Conference Series: Earth and Environmental Science, 8, available from: http://iopscience.iop.org/17551315/8/1/012005/pdf/1755-1315_8_1_012005.pdf.

Tropp, J. 2003. Displaced people, replaced narratives: forest conflicts and historical perspectives in the Tsolo district, Transkei. Journal of Southern African Studies, 29(1), 207-233.

US Department of State (USDS). 2008. Joint statement by United States and Brazil on energy security [online]. Office of the Spokesman. Available from: http://www.america.gov/st/texttransenglish/2008/November/20081120140136eaifas0.879513.html [Accessed 30 August 2009].

Utting, P. and J. Clapp, eds. 2008. Corporate accountability and sustainable development. Delhi: Oxford University Press.

Vandergeest, P. and N.L. Peluso. 2006a. Empires of forestry: professional forestry and state power in Southeast Asia, Part 1. Environment and History, 12, 31-64.

Vandergeest, P. and N.L. Peluso. 2006b. Empires of forestry: professional forestry and state power in Southeast Asia, Part 2. Environment and History, 12, 359-393.

Vargas Hill, R. 2009. Using stated preferences and beliefs to identify the impact of risk on poor households. Journal of Development Studies, 45(2), 151-171.

Vedeld, P., A. Angelsen, J. Bojö, E. Sjaastad and G.K. Berg. 2007. Forest environmental incomes and the rural poor. Forest Policy and Economics, 9, 869-879.

Vel, J. 2010. Jatropha in Eastern Indonesia: the commoditization of an alternative biofuel crop for marginal areas. Journal of Peasant Studies, 37(3).

Wegren, S.K. 2008. Typologies of household risk-taking: contemporary rural Russia as a case study. Workshop paper for the Agrarian Studies Colloquium, Yale University, 22 February 2008.

Wilkinson, J. and S. Herrera. 2010. Biofuels in Brazil: debates and impacts. Journal of Peasant Studies, 37(3).

Wright, E.O. 2006. Class analysis. In: R.F. Levine, ed. Social class and stratification: classic statements and theoretical debates, 2nd ed. Lanham, MD: Rowman and Littlefield, pp. 143-166.

Peter Dauvergne is Professor of Political Science, Canada Research Chair in Global Environmental Politics, and Director of the Liu Institute for Global Issues at the University of British Columbia. He has published 7 books, 2 monographs, and over 50 articles. His recent book, The Shadows of Consumption (MIT Press), won the 2009 Gerald L. Young Award, presented by the Society of Human Ecology for the best book authored in 2008 in the field of human ecology.

Kate J. Neville is a PhD student in the Department of Political Science, University of British Columbia. She holds a Bachelor of Science degree in Biology from Queen's University and a Master's of Environmental Science from Yale University. Her latest publication (with Peter Dauvergne) is 'The Changing North-South and South-South Political Economy of Biofuels', Third World Quarterly 30 (6) (2009): 1087-1102.

Corresponding author: Peter Dauvergne, Liu Institute for Global Issues, University of British Columbia, 6476 NW Marine Drive, Vancouver, BC, V6T 1Z2, Canada. Email: peter.dauvergne@ubc.ca. 